\title{
IMPLEMENTASI SMS GATEWAY UNTUK MENINGKATKAN JUMLAH KUNJUNGAN di POSYANDU CATLEYA 14 JEMBER
}

\section{THE IMPLEMENTATION OF SMS GATEWAY TO INCREASE THE NUMBER OF VISITS INPOSYANDU CATLEYA 14 JEMBER}

\author{
${ }^{1}$ Atma Deharja, ${ }^{2}$ Vita Permatasari \\ ${ }^{1,2}$ Prodi Rekam Medik Jurusan Kesehatan Politeknik Negeri Jember \\ Jln Mastrip Kotak Pos 164 Jember \\ 1atma.deharja@gmail.com
}

\begin{abstract}
Abstrak
Kesehatan balita adalah harapan setiap orang tua.Salah satu upaya yang dapat dilakukan untuk meningkatkan kesehatan balita dan balita adalah dengan pemberian vaksin kekebalan tubuh melalui imunisasi di Posyandu.Berdasarkan survei pendahuluan yang dilakukan, diketahui bahwa persentase kehadiran balita di Posyandu Catleya 14 sebesar 70\%.Kondisi tersebut menunjukkan bahwa angka kunjungan balita di wilayah kerja Posyandu Catleya 14 tersebut belum memenuhi target yang telah ditetapkan, yaitu di atas 85\% untuk Posyandu strata mandiri.Rendahnya persentase ketercapaian kehadiran balita disebabkan oleh sebagian besar ibu balita lupa atau tidak mengetahui waktu pelaksanaan Posyandu di wilayahnya.Perancangan Sistem Informasi Reminder Kegiatan Posyandu berbasis SMS Gateway hadir sebagai solusi.Metode yang digunakan adalah waterfall. Setelah melakukan analisa, tahapan selanjutnya adalah desain sistem, desain tampilan sistem, dan desain format sms yang akan dikirimkan. Lalu dilakukan pengkodean dan pengujian.Hasil penelitian adalah terciptanya aplikasi dengan fitur-fitur otomatis yang mampu menyelesaikan masalah tersebut dan mudah untuk digunakan oleh kader posyandu.Setelah diterapkannya SMS Gateway, terjadi peningkatan jumlah kehadiran balita dalam kegiatan posyandu.Sehingga dapat disimpulkan bahwa teknologi SMS Gateway telah dibuat dan mampu meningkatkan jumlah kunjungan Posyandu Catleya 14.
\end{abstract}

Kata kunci:Sistem informasi, SMS Gateway, Posyandu, Waterfall

\begin{abstract}
Infant health is the hope of every parent. One effort that can be done to improve the health of infants and toddlers are immune to the vaccine through immunization in IHC. Based on the preliminary survey, the percentage of children under five in the presence of Posyandu Catleya 14 by $70 \%$. The conditions show that the number of visits in the region of Posyandu Catleya 14, it did not meet the targets set, above $85 \%$. The low percentage of achievement for children under five are caused by the presence of the majority of mothers forget or do not know the timing of Posyandu in its territory. Reminder Information System Design based SMS Gatewaypresent as a solution. The method used is the waterfall. After analysis, the next step is a system design, system interface design, and design sms format that will be sent. Then do the coding and testing. Results of the research is the creation of applications with automated features capable of solving the problem and easy to use Posyandu staff. After the implementation of SMS Gateway, an increasing number of children under five in the presence of Posyandu activities. It can be concluded that the SMS Gateway technology has been created and is able to increase the number of PosyanduCatleya 14.
\end{abstract}

Keywords: Information System, SMS Gateway, Posyandu, Waterfall 


\section{PENDAHULUAN}

Kesehatan balita adalah harapan setiap orang tua, mengingat usia balita yang rentan terhadap penyakit merupakan ketakutan tersendiri bagi orang tua bukan tanpa alasan, hal ini terkadang karena kesibukan orang tua menyebabkan keterlambatan informasi penanganan kesehatan balita, sehingga banyak balita yang kurang memiliki kekebalan tubuh sempurna (Irawan,2008). Salah satu upaya yang dapat dilakukan untuk meningkatkan kesehatan balita dan balita adalah dengan pemberian vaksin kekebalan tubuh melalui imunisasi di Posyandu.

Berdasarkan hasil observasi di Posyandu Catleya 14, Kec. Sumbersari, Kab. Jember diketahui jumlah sasaran balita ditimbang pada bulan Maret sampai Mei 2016 sebanyak 103 balita.Data D/S yang didapatkan selama 3 bulan terakhir tidak menunjukkan adanya peningkatan yang signifikan dan masih berada dibawah nilai persentase ketercapaian kehadiran balita yang digunakan di Posyandu Catleya 14 Kecamatan Sumbersari.Rendahnya persentase ketercapaian balita menyebabkan status gizi balita tidak terpantau dengan baik.Ketidakhadiran ibu balita untuk kegiatan posyandu disebabkan karena banyaknya ibu balita yang lupa atau tidak mengetahui jadwal imunisasi.

Pemberitahuan tentang jadwal imunisasi dilakukan pada hari dilaksanakannya imunisasi melalui pengeras suara masjid. Karena sebagian besar dari ibu balita bekerja (55 orang atau 53,4\% dari 103 balita), mereka tidak mengetahui pengumuman tersebut. Banyaknya jumlah ibu balita bekerja yang tidak mengetahui informasi kegiatan posyandu menyebabkan rendahnya persentase balita ditimbang sehingga dibutuhkan sistem indornasi reminder kegiatan posyandu sebagai sarana dalam memberikan informasi dan mengingatkan ibu balita tentang jadwal posyandu.

Tujuan penelitian ini antara lain:

a. Menganalisis sistem yang ada di Posyandu Catleya 14 Kecamatan Sumbersari Kabupaten Jember.

b. Mendesain informasi reminder kehadiran kegiatan posyandu berbasis SMS Gateway di Posyandu Catleya 14 Kecamatan Sumbersari Kabupaten Jember.

c. Melakukan pengkodean

d. Melakukan pengujian sistem.

Manfaat penelitian ini adalah membantu memberikan teknologi sebagai reminder kegiatan untuk peserta posyandu Catleya 14 sehingga angka kehadiran balita meningkat dan kondisi kesehatan balita terpantau dengan baik.

Penelitian tentang SMSGateway telah banyak dilakukan.. Penjadwalan untuk pengiriman SMS yang berisi informasi berkaitan dengan ibu hamil[Heru L.]. Namun untuk pengetikan SMS masih dilakukan secara manual. Jadwal imunisasi setiap balita berbeda, karena harus sesuai dengan usia balita tersebut. Hal ini menyebabkan waktu yang dibutuhkan untuk memilih dan mengetik SMS satu persatu peserta posyandu menjadi lama.Penelitian ini sebagai solusi atas permasalahan tersebut. Di penelitian ini, pesan terkait jadwal imunisasi yang akan dikirimkan ke ibu balita peserta posyandu telah otomatis disediakan sesuai dengan usia balita. Sehingga user hanya cukup menekan satu tombol saja untuk mengirimkan pesan yang berbeda-beda. Namun, kader posyandu tetap disediakan layanan untuk mengedit atau mengetik manual isi pesan jika diperlukan.

\section{METODOLOGI}

Jenis penelitian ini adalah penelitian kualitatif berupa pembuatan sistem informasi reminder kehadiran kegiatan posyandu berbasis SMS Gateway.Penelitian ini menggunakan perancangan pemograman dengan metode waterfall, meliputi analisis, desain, pengkodean dan pengujian serta implementasi sistem. Subyek penelitian adalah kader posyandu sebagai user aplikasi SMS gateway.

Dalam tahapan analisis dilakukan pengumpulan data.Pengumpulan data dilakukan dengan wawancara dan observasi.Pendekatan yang digunakan adalah cross sectional, artinya pengambilan data dilakukan pada saat bersamaan.Setelah data didapatkan, dilakukan pengolahan data menggunakan analisis konten.Data diolah untuk mendapatkan penggambaran keadaan sistem telah berjalan, kemudian dibuat flowchart sistem dan dilakukan analisis kebutuhan untuk sistem SMS Gatway.Selanjutnya, membuat desain berupa flowchart sistem SMS Gateway, diagram konteks serta desain tampilan antarmuka sistem. Sistem yang telah didesain, dikode menggunakan visual basic dengan menggunakan database ms. access.Sistem diuji per unit kemudian diintegrasikan dan diuji secara keseluruhan. Setelah itu, sistem diimplementasikan pada posyandu Catleya 14

\section{HASIL DAN PEMBAHASAN}

Metode yang digunakan adalah metode waterfall, sehingga langkah-langkahnya sebagai berikut

a. Analisis

Melalui survei pendahuluan, diketahui bahwa terdapat permasalahan yaitu rendahnya persentase ketercapaian kehadiran balita dalam kegiatan posyandu.Hal ini menyebabkan status gizi balita tidak terpantau dengan baik.Penyebab utama adalah ketidakhadiran ibu balita dalam kegiatan posyandu disebabkan karena banyaknya ibu balita peserta posyandu yang lupa jadwal imunisasi, selain itu banyak pula ibu balita yang bekerja, sehingga pengumuman yang disampaikan melalui speaker masjid pada pukul 08.30 tidak diketahui. Dibutuhkan suatu solusi untuk mengingatkan ibu balita akan kegiatan posyandu. Sistem informasi reminder untuk meningkatkan jumlah kehadiran ibu balita untuk kegiatan posyandu berbasis SMS Gateway.Pengguna sistem ini adalah kader posyandu Catleya 14.

Untuk memahami kerja dari sistem yang ada, dilakukan pengumpulan data melalui wawancara dan observasi.Wawancara dan observasi dilakukan terhadap kader-kader posyandu Catleya 14 yang berjumlah 7 orang.Ketujuh responden berjenis kelamin wanita dengan umur rata-rata 50 tahun.Melalui wawancara, diperoleh informasi bahwa posyandu dikelola yang didampingi oleh bidan desa setempat ini memberikan pelayanan lengkap yaitu penimbangan balita dan balita, pemberian imunisasi dan vitamin, pemeriksaan kehamilan, penyuluhan kesehatan dan gizi.Posyandu ini di bawah pengawasan Puskesmas Sumbersari.Respondenmemiliki laptop dan hp android serta telah terbiasa menggunakannya.Hal ini menujukkan bahwa meskipun berusia lanjut, mereka mampumenerima dan menggunakan teknologi sistem 
informasi reminder berbasisSMS Gateway.Namun desain harus dibuat sesederhana mungkin, dan semirip mungkin dengan antarmuka yang disediakan handphone untuk mengirim SMS.Semakin sederhana desain, semakin mudah responden mengingat langkah-langkah dalam penggunaan sistem baru karena tidak harus menghafal banyak.Responden juga menginginkan tampilan antar muka sederhana, tidak banyak gambar, jelas dan mencakup data sosial lengkap. Perbandingan sistem lama dan baru dapat dilihat pada Tabel 1.1 berikut ini:

Tabel 1. Perbandingan sistem lama dan baru

\begin{tabular}{|c|c|c|}
\hline Kegiatan & Sistem Lama & Sistem baru \\
\hline $\begin{array}{l}\text { Pemberitahuan } \\
\text { kegiatan } \\
\text { posyandu }\end{array}$ & $\begin{array}{lr}\text { Manual melalui } \\
\text { spaker masjid } \\
\text { pada jam } 08.30 \\
\text { hari yang sama } \\
\text { dengan } \\
\text { pelaksanaan } \\
\text { kegiata posyandu }\end{array}$ & \begin{tabular}{lr}
\multicolumn{2}{l}{ Otomatis melalui } \\
SMS yang \\
dikirimkan \\
langsung ke \\
peserta posyandu
\end{tabular} \\
\hline $\begin{array}{l}\text { Isi pesan } \\
\text { pemberitahuan }\end{array}$ & $\begin{array}{l}\text { Bersifat global, } \\
\text { hanya } \\
\text { menyebutkan } \\
\text { bahwa akan } \\
\text { diadakan } \\
\text { kegiatan } \\
\text { posyandu pada } \\
\text { hari tersebut }\end{array}$ & 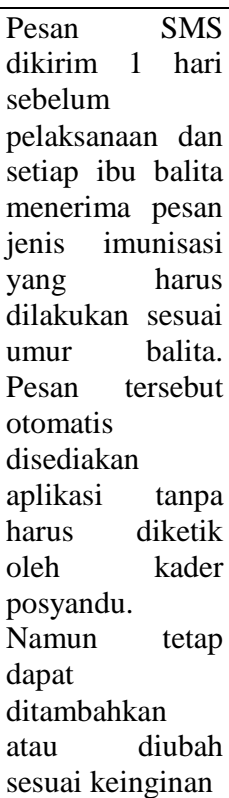 \\
\hline $\begin{array}{l}\text { Pencatatan } \\
\text { data balita }\end{array}$ & $\begin{array}{l}\text { Dicatat } \\
\text { manual di buku } \\
\text { induk }\end{array}$ & $\begin{array}{l}\text { Disimpan } \\
\text { otomatis } \\
\text { database }\end{array}$ \\
\hline $\begin{array}{l}\text { Penentuan } \\
\text { umur bayi } \\
\text { dalam bulan }\end{array}$ & Dihitung manual & Otomatis \\
\hline
\end{tabular}

Kegiatan imunisasi dilakukan setiap bulan di akhir minggu kedua, sehingga tanggal setiap bulannya tidak dapat dipastikan.Pemberitahuan dilakukan menggunakan pengeras suara di masjid pada pukul 08.30 pagi. Kondisi tersebut masih kurang efektif karena banyak ibu balita tidak mendengar pemberitahuan dan tidak mengetahui akan adanya kegiatan imunisasi. Hal ini didukung dengan data banyaknya jumlah ibu yang bekerja yang pada waktu tersebut sedang tidak berada di rumah.Setiap peserta posyandu melakukan kunjungan, data balita direkap di buku induk. Data tersebut mencakup data nama balita, nama orang tua, tanggal lahir balita, jenis kelamin balita, umur balita, alamat, data imunisasi setiap kunjungan. Penelitian ini berfokus pada reminder kegiatan untuk meningkatkan angka kunjungan sehingga tidak menyediakan fasilitas pencatatan data kunjungan.Umur balita seharusnya dituliskan dengan satuan bulan, sedangkan peserta posyandu sering meyebutkan umur balita dalam satuan tahun, sehingga kader posyandu perlu menghitung terlebih dahulu dan mengkonversikannya dalam bulan. Dalam proses perhitungan inilah sering terdapat perbedaan pendapat antar kader dalam menentukan umur balita. Umur balita erat kaitannya dengan jenis imunisasi yang diberikan untuk balita.Setelah mendapatkan imunisasi campak, sebagian besar peserta posyandu (ibu balita) tidak lagi membawa KMS (Kartu Menuju Sehat), sehingga kader kebingungan dalam mencatat riwayat balita.

Tabel perbandingan sistem yang ada dengan sistem baru ditunjukkan Tabel 1.Alur kegiatan posyandu digambarkan dalam flowchart yang ditunjukkan Gambar 1.Diagram konteks ditunjukkan Gambar 2.

b. Pengkodean

Pengkodean dilakukan menggunakan visual basic.net. Form yang dibuat adalah form password, form pesan, form kontak, form listkontak. Form password berfungsi sebagai pengaman agar tidak semua orang dapat mengakses sistem . Form pesan digunakan untuk mengirimkan SMS, form kontak digunakan untuk menambahkan data peserta posyandu baru atau mengubah data peserta posyandu yang telah disimpan sebelumnya. Form listkontak menampilkan database peserta posyandu yang disimpan.

Tampilan form password ditunjukkan Gambar 1, tampilan form pesan ditunjukkan Gambar 2. Tampilan form kontak ditunjukkan Gambar 3. Tampilan form ListKontak ditunjukkan Gambar 4.

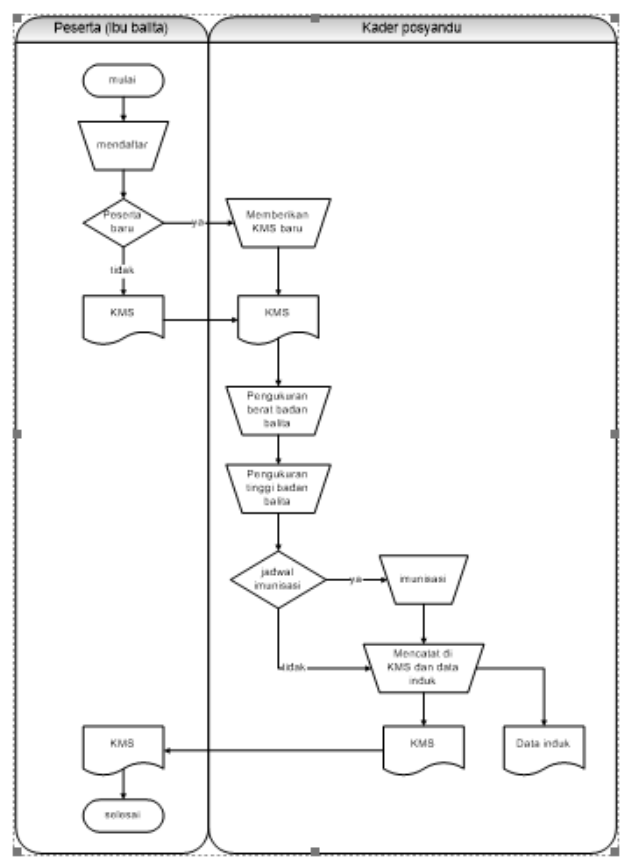

Gambar 1 Alur kegiatan posyandu

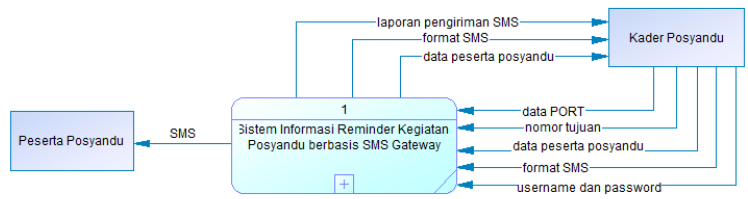

Gambar 2 Diagram konteks

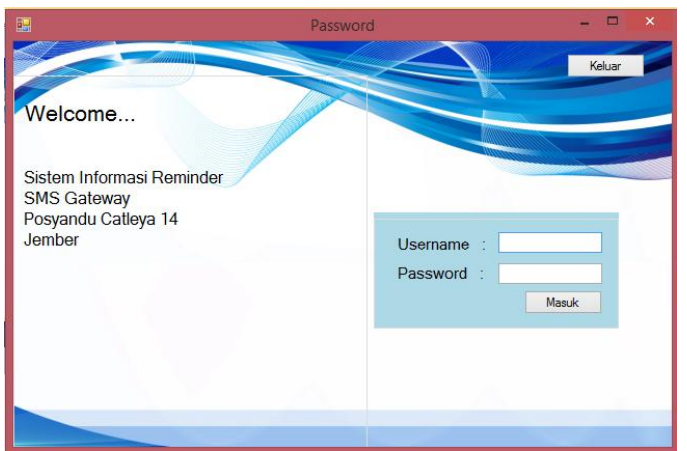

Gambar 3. Form password 


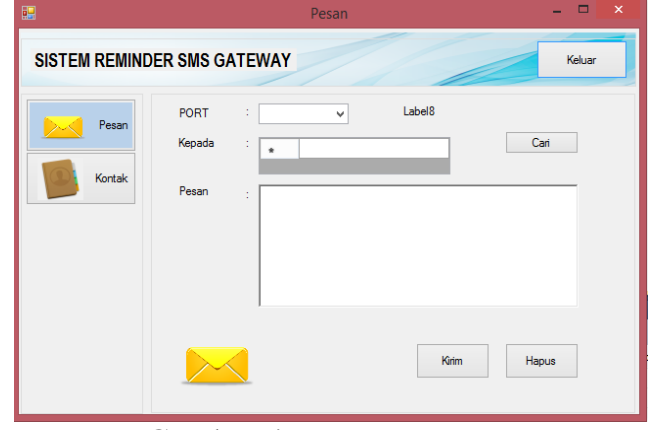

Gambar 4. Form pesan

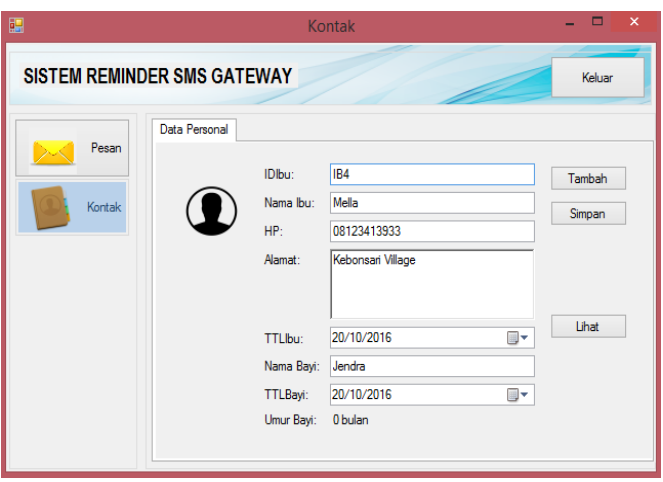

Gambar 5. Form kontak

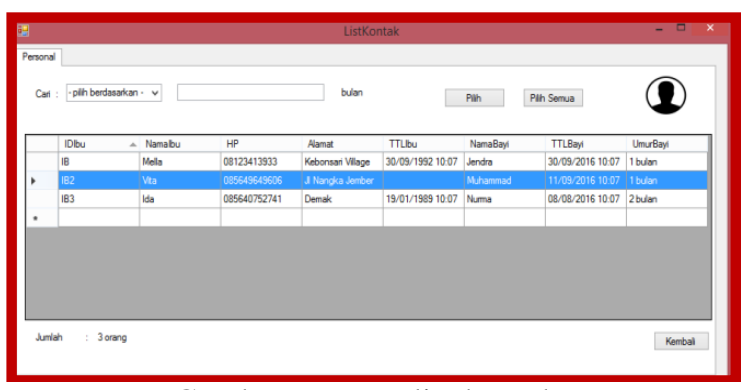

Gambar 6. Form list kontak

\section{KESIMPULAN}

Analisis kebutuhan sistem yang ada di Posyandu Cateliya 14 Kecamatan Sumbersari Kabupaten Jember yaitu berupa sistem informasi reminder yang mudah dioperasikan, dengan tampilan program yang sederhana yang dapat memberikan informasi pengumuman kegiatan posyandu.

Desain Sistem Informasi Reminder Kehadiran Kegiatan Posyandu Berbasis SMS Gateway di Posyandu Cateliya 14 Kecamatan Sumbersari Kabupaten Jember berupa flowchart system menggunakan microsoft visio 2007, DFD (data flow diagram) mulai dari diagram konteks hingga DFD level 0 dengan menggunakan power designer, basis data dengan Ms.Access.

Pengkodean program sesuai dengan desain yang telah dibuat pada Perancangan Sistem Informasi Reminder Kehadira Keginatan Posyandu Berbasis SMS Gateway di Posyandu Cateliya 14 Kecamatan Sumbersari Kabupaten Jember dimana aplikasi ini

dibuat menggunakan VB.net sehingga coding yang digunakan sesuai dengan bahasa pemrograman tersebut. Dalam pengujian dan implementasi Posyandu Cateliya 14 Kecamatan Sumbersari Kabupaten Jember dimana semua form berhasil dan user (kader posyandu) dapat menggunakan dengan mudah.

\section{UCAPAN TERIMA KASIH}

Tim penelitian mengucapkan terima kasih kepada Posyandu Catleya 14 Jember dan Politenik Negeri
Jember atas dukungan pendanaan sehingga kegiatan ini dapat terlaksana dengan baik.Kegiatan penelitian ini menjadi salah satu bentuk implemetasi Politeknik Negeri Jember untuk dapat mengatasi masalah yang sedang dihadapi.Kegiatan penelitian dilaksanakan di Posyandu Catleya 14 Jember Jember dalam upaya pencegahan masalah kesehatan.

\section{DAFTAR PUSTAKA}

A.S Rosa dan Salahuddin M.2011. Modul Pembelajaran Rekayasa Perangkat Lunak (Terstruktur dan Berorientasi Objek), Modula, Bandung.

Departemen Kesehatan RI.2006.Pedoman Umum Pengelolaan Posyandu.

Departemen Kesehatan RI.2009.Imunisasi Dasar Rutin Serta Kesehatan Ibu dan Anak Bagi Kader, Petugas Lapangan dan Organisasi Kemasyarakatan

Novelia, M.N.R.2014. Analisis dan Perancangan Aplikasi Pengingat Waktu Imuisasi pada Bayi di Puskesmas Gondokusuman 1 Yogyakarta. Jurusan Sistem Informasi, Perguruan Tinggi Manajemen Informatika dan Komputer AMIKOM. Yogyakarta.

L. Heru Cahya Rustamaji, Wilis Kaswidjanti, Aplikasi sms pengingat ibu hamil, di Seminar Nasional Informatika, 2008, pp. 157-166.

Peraturan Menteri Kesehatan RI. Nomor 42 Tahun 2013.Tentang Penyelenggaraan Imunisasi.

Setiawan, Wahyu. Sistem Informasi Posyandu Dengan SMS Gateway Menggunakan Metode Ontology dalam Menjawab Pertanyaan 